\title{
INFLUENCE OF GLYCAEMIA AND HBAIC LEVELS AT ADMISSION OF INSULIN-INDEPENDENT DIABETES PATIENTS ON THE LENGTH AND OUTCOME OF HOSPITALIZATION DUE TO NSTEMI/STEMI
}

\section{UTICAJ GLIKEMIJE I NIVOA HBAIC NA PRIJEMU NA DUŽINU I ISHOD HOSPITALIZACIJE KOD OBOLELIH OD INSULIN -NEZAVISNOG DIJABETESA SA NSTEMI/STEMI}

Pejka Kovacevic', Zoran Gluvic ${ }^{2}$, Biljana Putnikovic², Bozidarka Zaric ${ }^{3}$, Sasa Radenkovic, Ivana Resanovic ${ }^{3}$, Esma Isenovic ${ }^{3,}$

\section{Summary}

This study aims to examine the influence of admission glycaemia and glycosylated haemoglobin (HbA1C) levels on the length of hospitalization and its outcome in insulin-independent diabetes mellitus (DM) patients suffering from ST-Segment Elevation Myocardial Infarction (STEMI)/Non-STEMI (NSTEMI).

This cross-sectional study included 103 subjects with a history of insulin-independent DM, currently hospitalized due to acute myocardial infarction (AMI). Out of 103 subjects, 59 (57\%) were men and 66 (64.1\%) of them suffered from STEMI. Mean age of study population was $67 \pm 9$ years. The following parameters were monitored: demographic, coronary, cardiovascular and DM risk factors history, as well as laboratory, clinical, echocardiography and angiography parameters.

DM mean duration was 7 (1-30) months, and it influenced the length of hospitalization $(\rho=0.232, p<0.05)$, but not the outcome $(\rho=0.174, p>0.05)$. Mean length of hospitalization was 8 and 8.5 days in STEMI and NSTEMI patients respectively, with no difference between groups (log-rank $x 2=0.476$, $p>0.05)$. HbA1C values influenced the length of hospitalization $(p=0.213, p<0.05)$, opposite to admission glycaemia $(p=0.148, p>0.05)$.

Duration of DM and the level of HbA1C prolong the length of hospitalization, but do not influence the clinical outcome of AMI patients suffering from insulin-independent DM.

Key words: acute myocardial infarction, diabetes, glycaemia, $\mathrm{HbA1C}$

\section{Sažetak}

Cilj prikazane studije je izučavanje uticaja glikemije i glikoziliranog hemoglobina (HbA1C) pri prijemu u bolnicu na dužinu trajanja hospitalizacije, kao i njen ishod kod kod obolelih od insulin-nezavisnog dijabetesa sa NSTEMI/STEMI.

Materijal i metode: Ova studija je uključila 103 ispitanika, od kojih su 59 (57\%) ispitanici muškog pola, a 66 (64.1\%) ispitanika imalo STEMI. Prosečna

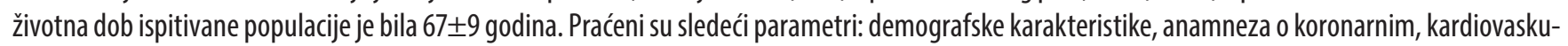
larnim i rizičnim faktorima za dijabetes, kao i laboratorijski, klinički, ehokardiografski parametri.

Rezultati: Prosečno trajanje dijabetesa kod osoba uključenih u studiju je bilo 7 (1-30) meseci i imalo je uticaj na dužinu hospitalizacije ( $\rho=0.232$, $p<0.05$ ), ali ne i na njen krajnji ishod ( $p=0.174, p>0.05$ ). Prosečno trajanje hospitalizacije je bilo 8 i 8.5 dana kod ispitanika sa STEMI i NSTEMI i nije se razlikovalo među grupama ispitanika (log-rank $x 2=0.476, p>0.05)$. Nivoi HbA1C su uticali na dužinu trajanja hospitalizacije $(\rho=0.213, p<0.05)$, što nije bio slučaj sa glikemijom pri prijemu u bolnicu $(\rho=0.148, p>0.05)$.

Zaključak: Dužina trajanja DM i nivo HbA1C produžavaju dužinu hospitalizacije, ali ne utiču na klinički ishod ispitanika sa insulin-nezavisnim dijabetesom koji su doživeli AIM.

Ključne reči: akutni infarkt miokarda, dijabetes, glikemija, Hba1C

\section{INTRODUCTION}

Acute myocardial infarction (AMI) is a clinical form of coronary heart disease, which occurs during occlusion of the coronary artery and is histologically defined as myocardial necrosis ${ }^{1}$. Diabetes mellitus (DM) is a metabolism disorder of carbohydrates, fats and proteins induced by absolute or relative insulin deficiency. The phenomenon of accelerated atherosclerosis, as the essence of $\mathrm{DM}$, is caused by co-action of genetic and non-genetic factors which lead to serious cardio-, cerebral- and peripheral vascular morbidity. This phenomenon dominates in small blood vessels in type $1 \mathrm{DM}$ as well in macrovascular circulation in type $2 \mathrm{DM}(2,3)$. More than $60 \%$ of DM patients die from vascular complications, whereby mortality rate of DM patients suffering from AMI and acute brain stroke is 2-4 times higher than in persons not suffering from DM. An acute disturbance in glycaemia often follows AMI, rarely presented as diabetic ketoacidosis. Poor glycemic control associated with an 
acute coronary event almost always deranges glycosylated haemoglobin (HbAlC) levels (4-6).

This study aims to present epidemiological, clinical and angiographic features of ST-Segment Elevation Myocardial Infarction (STEMI)/Non-STEMI (NSTEMI) in insulin-independent DM patients, as well as the effect of hospital admission glycaemia and $\mathrm{HblC}$ levels on the length and outcome of hospitalization.

\section{MATERIAL AND METHODS}

This cross-sectional study included 103 subjects, who were hospitalized at the Coronary Care Unit of University Hospital Medical Center (UHMC) Bezanijska Kosa due to the AIM with STEMI (66 subjects) or AIM without ST elevation (NSTEMI) (37 subjects), with already diagnosed and treated insulin-independent DM. The exclusion criteria were the previous insulin treatment, recent coronary event (within 6 months), invasive and surgical treatment of heart or other diseases surgically managed (all requiring temporary or permanent insulin treatment).

The following parameters were monitored: demographic (sex, age), previous risk factors history (for coronary and cardiovascular disease as well as DM), laboratory (haematological and biochemical), clinical (signs of heart failure (HF), arterial blood pressure, presence of rhythm or conduction disorders, length of hospitalization, outcome of disease), as well as echocardiography and angiography findings.

Local Ethic Committee approved the study. A written agreement of subjects to the mentioned invasive procedure was taken as mandatory.

\section{HAEMATOLOGY ANALYSIS}

Haemoglobin level was determined on Pentra 120 micros 60 analyser (HORIBA ABX SAS, Kyoto, Japan) and values are expressed in $\mathrm{g} / \mathrm{L}$.

\section{BIOCHEMICAL ANALYSIS}

\section{Measurement of plasma glucose}

Admission plasma glucose levels were measured by a standardized GLUC-PAP method on Roche Cobas c 501 analyzers (Roche Diagnostics, Indianapolis, USA), according to the $\mathrm{m} 7$. nufacturer's guidelines. Level of glycaemia is expressed in $\mathrm{mmol} / \mathrm{l}$.

\section{Measurement of HbA1C}

The specific measurement of $\mathrm{HbAlC}$ was carried out using an immunological method with an antibody to the beta chain of HbA1C, on Roche Cobas c 501 analyser (Roche Diagnostics, Indianapolis, USA). The HbA1C test result is reported as a percentage (\%).

\section{Measurement of creatine kinase (CK)}

The concentration of $\mathrm{CK}$ was measured using in vitro test for quantitative determination of $\mathrm{CK} \mathrm{MB}$ subunit (CK-MB) catalytic activity in human serum, on Roche Cobas c 501 analyzer (Roche Diagnostics, Indianapolis, USA). The CK activity in the sample is expressed in U/L.

\section{Measurement of troponin T}

The concentration of troponin $\mathrm{T}$ values was measured on automated VIDAS ${ }^{\circledast}$ instrument, following manufacturer's guidelines, using the enzyme-linked fluorescent immunoassay, VIDAS Troponin I Ultra assay (bioMérieux, Marcy L'Etoile, France). Troponin T concentration is expressed in $\mathrm{ng} / \mathrm{ml}$.

\section{Measurement of creatinine concentration}

The measurement of creatinine was carried on Roche Cobas c 501 analyzer (Roche Diagnostics, Indianapolis, USA). The creatinine concentration was expressed in $\mu \mathrm{mol} / \mathrm{L}$.

\section{Measurement of serum potassium ion concentration}

The concentration of potassium ion in serum was determined on Roche Cobas c 501 analyzer (Roche Diagnostics, Indianapolis, USA). Briefly, this method determines potassium ion concentration by indirect potentiometry using a potassium ion selective electrode. The potassium ion concentration is expressed in $\mathrm{mmol} / \mathrm{l}$.

\section{Measurement of triglycerides (TC) and total LDL and HDL cholesterol concentration}

The concentration of TG was measured using a commercially available kit according to the manufacturer's guidelines, carried on a Roche Cobas c 501 analyzer (Roche Diagnostics, Indianapolis, USA). Total cholesterol was determined by standardized enzymatic colour test (enzymatic assay), using cholesterol oxidase-peroxidase enzyme. The values of LDL were calculated using Friedewald's equation.

$$
\mathrm{LDL}=\text { total cholesterol }-\mathrm{HDL}-0.45 \times \mathrm{TG}[\mathrm{mmol} / \mathrm{l}]
$$

HDL-cholesterol was determined by the precipitation method with sodium phosphowolframate. LDL and HDL cholesterol concentrations were expressed in $\mathrm{mmol} / \mathrm{l}$.

\section{Measurement of Serum C-reactive protein (CRP) \\ Concentration}

The concentration of CRP in serum was measured by the immunoturbidimetric method using a commercially available kit (System reagent for the quantitative determination of CRP in human serum), following manufacturer guidelines, on Roche Cobas c 501 analy- 
ser (Roche Diagnostics, Indianapolis, USA). The results were expressed in $\mathrm{ng} / \mathrm{L}$.

\section{CLINICAL, ECHOCARDIOGRAPHY AND ANGIOGRAPHY PARAMETERS}

Clinical parameters (HF signs), as well as the presence of rhythm and/or conduction disorders (as electrocardiogram-ECG), were monitored and registered upon the admission of subjects. Measuring of systolic and diastolic pressure was done with a Riestar precisa manometer and values were displayed in a millimetre mercury (mmHg) column. ECG was recorded with Nihon Kohden Cardiofix gem, on a $25 \mathrm{~mm}$ paper. An ejection fraction (in \%) was registered with the echocardiographic examination, conducted on Vivid 4 device, as well as the presence of wall kinetic disorders, presented as akinesia and hypokinesia. Angiography finding described left coronary artery (LCA) and/or left anterior descending (LAD) stenosis in \%, as well as precise location of an acute lesion (expressed as stenosis in \%). Angiography was conducted at UHMC Bezanijska Kosa.

\section{STATISTICAL METHODOLOGY}

Methods of descriptive (relative numbers, central tendency and variability measures) and analytical statistics were used. Regarding the analytical statistics methods, tests for assessment of correlation significance (Spearman rank correlation test) and difference ( $\chi^{2}$ and Mann-Whitney test) were used. The Kaplan-Meier survival curve was used for calculating the length of hospitalization per groups of subjects in relation to the outcome of a disease; the comparisons of obtained values were performed by a Log-rank test. Level of statistical significance was 0.05 .

\section{RESULTS}

The average age of study subjects was $67 \pm 9$ (46-92 years) and did not differ between groups $(\mathrm{Z}=-0.389, \mathrm{p}>0.05)$. Results show that age influenced the length of hospitalization $(\rho=0.261, p<0.01)$. No statistically significant difference in the distribution of subjects per groups according to the gender was registered $\left(\chi^{2}=0.246, D F=1\right.$, $\mathrm{p}>0.05$ ).

Clinical parameters of the studied subjects' are presented in Table 1. The difference was registered in the case of HF presence $\left(\chi^{2}=5.117, \mathrm{DF}=1, \mathrm{p}<0.05\right)$. No significant differences in other observed parameters among studied groups were registered (subjects distribution per Killip classification, the presence of rhythm and conduction disorders). Average systolic and diastolic pressures were $149 \pm 31$ and $83 \pm 16 \mathrm{mmHg}$ and did not differ between groups. Out of 46 subjects with a HF, STEMI and NSTEMI were registered in 24 and 22 participants, respectively. The presence of HF influenced the hospitalization outcome $(\rho=-0.290, p<0.05)$. Five $(5 \%)$ subjects have had a family history for presence of DM, while $8(8 \%)$ subjects have had the family presence of DM and cardiovascular/coronary disease simultaneously. The median duration of DM in patients with STEMI and NSTEMI was 7 months, which was also the duration of DM treatment. Duration of DM had a significant influence on the length of current hospital treatment of the patients $(\rho=0.232, p<0.05)$, but not on the outcome of the disease $(\rho=0.174, p>0.05)$. Results presented in Fig. 1 shows that there were no differences among groups of subjects with regards to different DM treatment modalities $\left(\chi^{2}=0.464, D F=2, p>0.05\right)$.

\begin{tabular}{|ll} 
& Table 1. Clinical parameters \\
Parameter & n (\%) \\
\hline Heart Failure & $46(44.7)$ \\
Killip classification & I - $9(19.6)$ \\
& II $-30(65.2)$ \\
& III - 3 (6.5) \\
& IV $-4(8.7)$ \\
Rhythm disorder & $25(24.3)$ \\
Conduction disorder & $4(3.9)$
\end{tabular}

Figure 1. Treatment modalities of DM

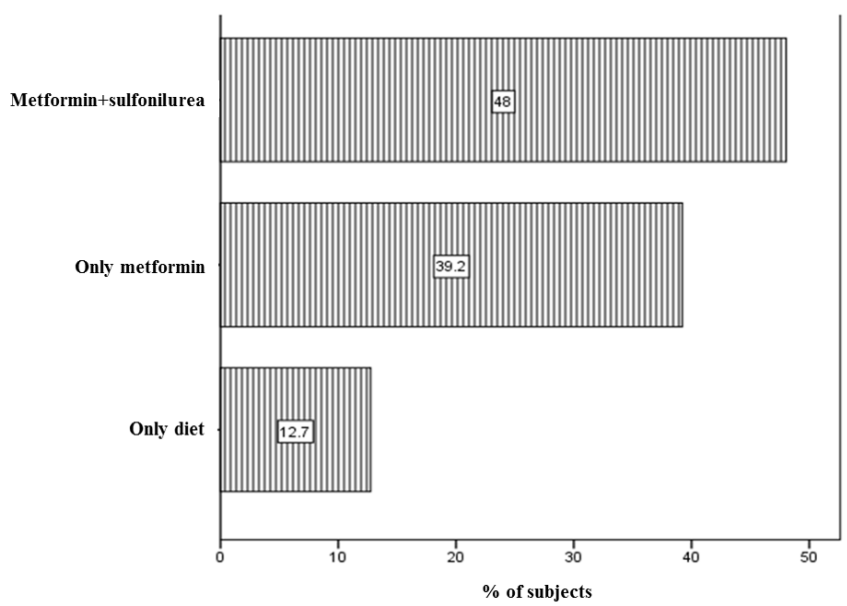

The analysis of risk factors for coronary/cardiovascular diseases revealed 40 (39\%) active and 16 (15\%) former smokers. Also, dyslipidaemia (regardless of whether it was treated or not) was present in $54(52.4 \%)$ subjects. The previous history of coronary/cardiovascular disease was documented in 49 (47.6\%) examinees.

Regarding echocardiography, average EF was $40 \pm 10$ (15-60\%) and did not differ between groups $(t=0.752$, $\mathrm{DF}=101, \mathrm{p}>0.05)$. The disorders of wall kinetics were detected in 99 (96\%) subjects: akinesia and dyskinesia in 73 (71\%) and 26 (25\%) subjects. Angiography-detected stenosis on LCA and LAD was registered in $20(19 \%)$ and $86(83 \%)$ subjects, with average stenosis of $70(20-$ $96)$ and 83 (30-100) \%. Acute lesion and, at the same time, the place of stent insertion, was localized in LAD, circumflex coronary artery $(\mathrm{ACx})$ and right coronary 
artery (RCA) in $42(40 \%), 23(22 \%)$ and $35(34 \%)$ subjects respectively, with average stenosis of $95 \pm 5$ (75-100) $\%$. Table 2 presents results of average initial values of laboratory parameters in the observed population.

Table 2. Initial hematological and biochemical parameters

\begin{tabular}{ll} 
Parameter & Average value \\
Glycaemia - mmol/L [Med] & $10.9(4.5-37.0)$ \\
\hline HbAlC - \% [Mean] & $7.4 \pm 1.6$ \\
CK - U/L [Med] & $171(40-1807)$ \\
Troponin - ng/ml [Med] & $0.63(0.01-30.0)$ \\
Total cholesterol - mmol/L [Mean] & $5.5 \pm 1.3$ \\
LDL cholesterol - mmol/L [Mean] & $3.4 \pm 0.9$ \\
HDL cholesterol - mmol/L [Med] & $1.0(0.5-3.8)$ \\
TG - mmol/L [Med] & $2.0(0.6-16.8)$ \\
Hemoglobin - g/L [n (\%)] & $<100-5(5)$ \\
& $\geq 100-98(95)$ \\
Potassium - mmol/L [Mean] & $4.4 \pm 0.5$ \\
Creatinine - $\mu$ mol/L [Med] & $95(38-479)$ \\
CRP - ng/L [Med] & $8.7(0.01-270)$
\end{tabular}

Abbreviations: HbA1C - Glycosylated Haemoglobin; CK - Creatine Kinase; LDL - Low-density lipoprotein; HDL - High-density lipoprotein; TG - Triglyceride CRP - C-reactive protein

The average length of hospitalization was 8.25 (2-22) days. In subjects with STEMI and NSTEMI it was 8 and 8.5 days, and it did not differ between groups (log-rank $\chi^{2}=0.476, p>0.05$ ) (Fig. 2). Admission glycaemia level did not have a significant effect on length of hospitalization $\left(\rho_{\text {gly }}=0.148, p>0.05\right)$, as opposed to HbAlC levels $\left(\rho_{\mathrm{HbAlC}}=0.213, \mathrm{p}<0.05\right)$.

Out of the total number of subjects, four (3.9\%) died at the hospital, three of those subjects had STEMI, and one had NSTEMI. With regards to the outcome of the disease, no statistically significant difference between examined groups was detected $\left(\chi^{2}=0.216, \mathrm{DF}=1\right.$, $\mathrm{p}>0.05)$. Admission glycaemia and $\mathrm{HbA1C}$ level did not influence the outcome of the disease $\left(\rho_{\text {gly }}=0.165, \rho_{\mathrm{H}-}\right.$ $\left.{ }_{\text {bAlC }}=0.047, \mathrm{p}>0.05\right)$.

Figure 2. Kaplan-Meier curve for the length of hospitalization in both outcomes of the disease with regard groups of subjects

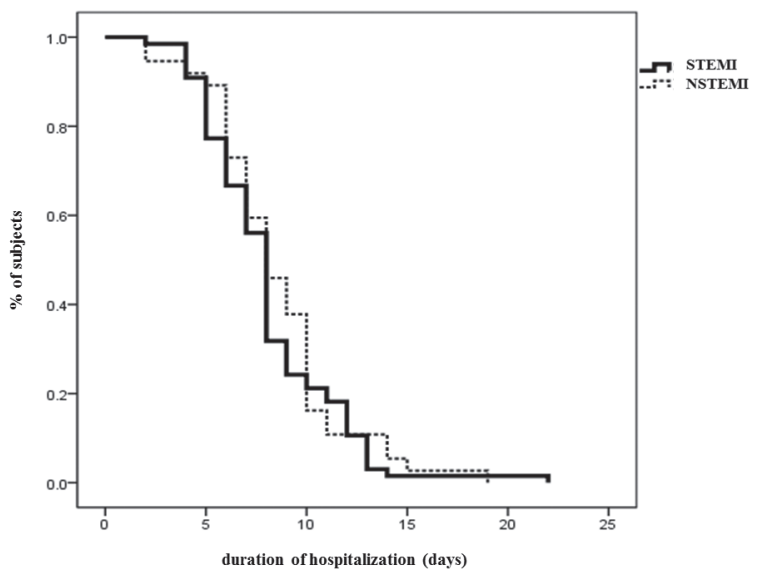

Abbreviation: STEMI - ST-Segment Elevation Myocardial Infarction; NSTEMI - Non-STEMI
In Table 3, some of the demographic, previous history and clinical parameters were presented, whereas Table 4 shows frequency distribution of subjects according to the types of DM treatment, and laboratory parameters per group of subjects were presented in Table 5.

Table 3. Demographic, previous history and clinical parameters per group of subjects

\begin{tabular}{|c|c|c|}
\hline Parameter & $\begin{array}{l}\text { STEMI } \\
(\mathrm{n}=66)\end{array}$ & $\begin{array}{l}\text { NSTEMI } \\
(\mathbf{n}=37)\end{array}$ \\
\hline Male gender [n (\%)] & $39(59)$ & $20(54)$ \\
\hline Age [Mean] & $67 \pm 9$ & $67 \pm 9$ \\
\hline Smoking habit [yes (\%)] & $27(41)$ & $13(35)$ \\
\hline $\begin{array}{l}\text { Positivehistory of dyslipidemia } \\
\text { [yes(\%)] }\end{array}$ & $30(45)$ & $24(65)$ \\
\hline $\begin{array}{l}\text { Positive family history of dyslipidemia } \\
\text { [yes }(\%)] \text { : } \\
\text { - coronary/cardiovascular disease } \\
\text { - DM } \\
\text { - coronary/cardiovascular disease + DM }\end{array}$ & $\begin{array}{l}30(45) \\
3(5) \\
4(6)\end{array}$ & $\begin{array}{l}19(51) \\
2(5) \\
4(11)\end{array}$ \\
\hline HF [yes (\%)] & $24(36)$ & $22(60)$ \\
\hline Rhythm disorders [yes (\%)] & $12(18)$ & $13(25)$ \\
\hline Conduction disorders [yes (\%)] & $3(4)$ & $1(3)$ \\
\hline
\end{tabular}

Abbreviations: HF - Hart Failure; DM - Diabetes Mellitus

Table 4. The frequency distribution of subjects by DM treatment modalities

\begin{tabular}{|c|c|c|}
\hline Therapeutic modalities & STEMI & NSTEMI \\
\hline $\begin{array}{l}\text { Non-pharmacological } \\
\text { [yes (\%)] }\end{array}$ & $10(15)$ & $4(11)$ \\
\hline Metformin [yes (\%)] & $24(36)$ & $16(43)$ \\
\hline $\begin{array}{l}\text { Metformin + sulfonylurea } \\
\text { [yes (\%)] }\end{array}$ & $32(49)$ & $17(46)$ \\
\hline
\end{tabular}

Abbreviations: STEMI - ST-Segment Elevation Myocardial Infarction; NSTEMI - Non-STEMI

Table 5. The hematological and biochemical parameters in groups of studied subjects

\begin{tabular}{|c|c|c|c|}
\hline Parameter & STEMI & NSTEMI & $\mathbf{p}$ \\
\hline $\begin{array}{l}\text { Glycemia - mmol/L } \\
\text { [Med] }\end{array}$ & $11.7(4.5-37.0)$ & $10.3(6.4-34.0)$ & ns \\
\hline HbA1C - \% [Mean] & $7.4 \pm 1.6$ & $7.4 \pm 1.5$ & ns \\
\hline CK - U/L [Med] & $172(42-1807)$ & $171(40-1636)$ & ns \\
\hline Troponin - ng/ml [Med] & $0.88(0.01-30.0)$ & $0.56(0.01-4.3)$ & ns \\
\hline $\begin{array}{l}\text { Total cholesterol - } \\
\text { mmol/L [Mean] }\end{array}$ & $5.4 \pm 1.2$ & $5.7 \pm 1.4$ & ns \\
\hline $\begin{array}{l}\text { LDL cholesterol - mmo- } \\
\text { 1/L [Mean] }\end{array}$ & $3.3 \pm 0.9$ & $3.6 \pm 1.1$ & ns \\
\hline $\begin{array}{l}\text { HDL cholesterol - } \\
\text { mmol/L [Mean] }\end{array}$ & $1.0(0.4-3.8)$ & $0.9(0.6-1.8)$ & ns \\
\hline TG - mmol/L [Med] & $1.9(0.6-16.8)$ & $2.2(0.7-8.6)$ & ns \\
\hline $\begin{array}{l}\text { Hemoglobin - g/L [n } \\
(\%)]\end{array}$ & $\begin{array}{l}<100-4(6) \\
\geq 100-62(94)\end{array}$ & $\begin{array}{l}<100-1(3) \\
\geq 100-36(97)\end{array}$ & ns \\
\hline $\begin{array}{l}\text { Potassium - } \mathrm{mmol} / \mathrm{L} \\
\text { [Mean] }\end{array}$ & $4.4 \pm 0.5$ & $4.4 \pm 0.5$ & ns \\
\hline $\begin{array}{l}\text { Creatinine }-\mu \mathrm{mol} / \mathrm{L} \\
{[\mathrm{Med}]}\end{array}$ & $96(40-203)$ & $87(38-479)$ & ns \\
\hline CRP - ng/L [Med] & $8(0.4-270)$ & $10(0.0-103)$ & ns \\
\hline
\end{tabular}

Abbreviations: HbA1C - Glycosylated Haemoglobin; CK - Creatine Kinase; LDL - Low-density lipoprotein; HDL - High-density lipoprotein; TG - Triglyceride; CRP - C-reactive protein; STEMI - ST-Segment Elevation Myocardial Infarction; NSTEMI - Non-STEMI 


\section{DISCUSSION}

In the presented cross-sectional study, 103 subjects treated for insulin-independent DM, were hospitalized due to an acute coronary event, STEMI and NSTEMI. Influence of admission glycaemia on the length and outcome of hospitalization was not registered. Also, duration of DM and the level of HbA1C did not have significant effects on the current treatment outcome but prolonged the average length of hospitalization, which was not statistically different between studied groups.

Cardiovascular morbidity and mortality in patients suffering from insulin-independent DM is 2-5 times higher than in age-matched non diabetic persons (6). According to the GUSTO study, in-hospital mortality in DM patients was $10.6 \%$, and $6.2 \%$ in non-diabetic patients (7), which is not significantly different from overall mortality rate in our study (4\%). About $75 \%$ of patients suffering from insulin-independent DM die due to some macrovascular complication (coronary, peripheral or cerebrovascular disease). Cardiovascular disease is responsible for death of $75 \%$ patients suffering from insulin-independent, and $35 \%$ patients suffering from insulin-dependent DM (8).

Lipid profiles in our study population indicated mixed dyslipidaemia, increased level of LDL cholesterol and borderline protective level of HDL cholesterol. According to the United Kingdom Prospective Diabetes Study (UKPDS), the main risk factors for coronary disease in insulin-independent DM patients are increased LDL cholesterol, reduced HDL cholesterol, associated with the presence of hypertension, hyperglycaemia, and smoking (9). Almost half of the study subjects were former/present smokers, with concomitant presence of dyslipidaemia or any CVD, while less than $10 \%$ of subjects had a family history for DM and CVD. The most prevalent risk factors for CVD in DM patients, regardless of the type, were still hypertension and dyslipidaemia, whereby DM itself was also an independent risk factor. So, all of already mentioned support the fact of an extreme importance of primary and secondary prevention in DM and CVD $(6,9)$.

In our study, even mild increase in average CRP values that were significantly different among the examined groups indicated a presence of inflammation, which forms the basis of atherosclerosis (10). Additionally, the increased average systolic arterial pressure in our study also contributed to the acceleration of observed atherosclerosis $(2,4)$. The presence of HF additionally contributed to higher mortality rates due to the acute coronary syndrome in diabetes patients $(3,7,9)$. In our study, 46 (44.7\%) subjects had HF after an acute coronary event, slight frequently registered in patients suffering from STEMI. HF might also be considered as ominous sign in DM patients with an acute coronary syndrome $(7,9)$.

Coronary heart disease in DM patients occurs at an earlier age in comparison to subjects who are not suffering from
DM. There are more patients susceptible to complications and unfavourable outcomes in diabetes patients with coronary heart disease. An explanation for this could be in extension of atherosclerosis process as well as in somehow late reporting to physicians considering atypical disease presentation even clinically silent, because of autonomic neuropathy (6). Even though the duration of DM was relatively short (7 months on average in present study), patients were much earlier aware of hyperglycemia existence, but usually further tests considering the presence of $\mathrm{DM}$ and its complications were not undertaken. For this reason, the time of DM diagnosis setting sometimes coincides with the start of DM treatment (3).

In patients suffering from STEMI, primary coronary intervention is a management method of choice. By using drug-eluting stents, a better outcome quality is achieved regarding the reduction of some restenoses, long-term recovery, as well as a decrease in frequency of surgical revascularization (6, 11-13). Morphologically, atherosclerotic changes in coronary arteries in DM patients are diffuse, more extensive, frequently on two or three coronary blood vessels, usually unfavourable for dilatation (12). Hyperglycaemia and insulin resistance favour endothelial dysfunction, prothrombogenic state, protein glycosylation and vascular matrix deposition. Therefore, patients with DM and AIM have an increased risk of the unfavorable outcome of a percutaneous coronary intervention when compared to non-diabetic patients. Greater possibility of early in-stent thrombosis, restenosis, as well as negative vascular remodeling contributes to such outcome $(14,15)$. In present study, surgical revascularization was proposed in $40 \%$ of subjects, and this is in concordance with recommendations $(6,16)$.

Though they already suffered from DM, some of acute coronary patients ignore $\mathrm{DM}$ as disease $(5,8)$. Despite the low mortality rate from coronary disease in insulin-independent DM patients in this study, it is necessary once again to emphasize the importance of primary and secondary prevention of the coronary disease risk factors.

In conclusion, the results from this cross-sectional study did not show difference among groups regarding the length of hospitalization and its outcome in insulin-independent DM subjects, currently hospitalized due to NSTEMI or STEMI. Higher levels of HbA1C extended the duration of hospital treatment of coronary disease, which was not the case with admission glycaemia level. Acute and retroactive glycometabolic regulation did not influence the in-hospital outcomes of the disease in the observed population.

\section{ACKNOWLEDGEMENTS}

This study was partially funded by the grant (No. 173033) to E.R.I. from the Ministry of Science, Republic of Serbia. 


\section{COMPLIANCE WITH ETHICAL STANDARDS}

Ethical approval: All procedures performed in studies involving human participants were in accordance with the ethical standards of the institutional and/or national research committee and with the 1964 Helsinki dec- laration and its later amendments or comparable ethical standards.

Informed consent: Informed consent was obtained from all individual participants included in the study.

\section{REFERENCES}

1. Thygesen K, Alpert JS, Jaffe AS, Simoons ML, Chaitman BR, White HD, the Writing Group on behalf of the Joint ESC/ACCF/AHA/WHF Task Force for the Universal Definition of Myocardial Infarction. Third universal definition of myocardial infarction. Eur Heart J 2012;33:2551-67.

2. Gregg EW, Li Y, Wang J, Burrows NR, Ali MK, Rolka D, et al. Changes in diabetes-related complications in the United States. 1990-2010. N Engl J Me 2014;370:1514-23.

3. Desai JR, Vazquez-Benitez G, Xu Z, Schroeder EB, Karter AJ, Steiner JF, et al. Who Must We Target Now to Minimize Future Cardiovascular Events and Total Mortality? Lessons from the Surveillance, Prevention and Management of Diabetes Mellitus (SUPREME-DM) Cohort Study. Circ Cardiovasc Qual Outcomes 2015; 8:508-16.

4. Luscher TF, Creager MA, Beckman JA, Cosentino F. Diabetes and vascular disease: pathophysiology, clinical consequence and medical therapy: Part II. Circulation. 2003; 108:1655-61.

5. Fonseca VA. Risk factors for coronary heart disease in diabetes. Ann Intern Me 2000; 133(2):154-56.

6. Dandona P, Chaudhuri A. Diabetes: glycaemia and insulin after acute myocardial infarction. Nat Rev Endocrinol 2014; 10:448-50.

7. The GUSTO investigators. An international randomized trial compares four thrombolytic strategies for acute myocardial infarction. NEJM 1993; 329(10):673-82.

8. Preis SR, Pencina MJ, Hwang SJ, D'Agostino RB Sr., Savage PJ, Levy D, et al. Trends in cardiovascular disease risk factors in individuals with and without diabetes mellitus in the Framingham Heart Study. Circulation 2009; 120:212-20.

9. Turner RC, Millns N, Neil HA, Stratton IM, Manley SE, Matthews DR, et al. Risk factors for coronary artery disease in non-insulin dependent diabetes mellitus: UKPDS 23. BMJ 1998; 316:823-28.

10. Danesh J, Wheeler JG, Hirschfield GM, Gideon M, Eiriksdottir G, Rumley A, et al. C-reactive protein and other circulating markers of inflammation in the prediction of coronary heart disease. NEJM 2004 350:1387-97.

11. Task Force on the management of ST-segment elevation acute myocardial infarction of the European Society of Cardiology (ESC), Steg PG, James SK, Atar D, Badano LP, Blomstrom-Lundqvist C, Borger MA, et al. ESC Guidelines for the management of acute myocardial infarction in patients presenting with ST-segment elevation: The Task Force on the management of ST-segment elevation acute myocardial infarction of the European Society of Cardiology (ESC). Eur Heart J 2012; 33:2569-19.

12. Pajuenen O, Taskinen MR, Nieminen MS, Syvanne M. Angiography severity and extent of coronary artery disease in patients with type 1 diabetes mellitus. Am J Cardiol 2000; 86(10):1080-85.

13. Malberg K, Ryden L, Efendic S, Herlitz J, Nicol P, Waldenstrom A, et al. Randomized trial of insulin-glucose infusion followed by subcutaneous insulin treatment in diabetic patients with acute myocardial infarction (DIGAMI study): effects on mortality at one year. J Am Coll Cardiol 1995; 26(1):57-65.

14. Waller B, Palumbo P, Roberts W. Status of the coronary arteries at necropsy in diabetes mellitus with onset after age 30 years. Is J Med 1980; 69:498-506?

15. Cannon CP, Weintraub WS, Demopoulos LA, Vicari R, Frey MJ, Lakkis $\mathrm{N}$, et al. Comparison of early invasive and conservative strategies in patients with unstable coronary syndromes treated with the glycoprotein IIb/IIIa inhibitor tirofiban. NEJM 2001; 344(25):1879-87.

16. Roffi M, Patrono C, Collet J-P, Mueller C, Valgimigli M, Andreotti F, et al. 2015 ESC Guidelines for the management of acute coronary syndromes in patients presenting without persistent ST-segment elevation: Task Force for the Management of Acute Coronary Syndromes in Patients Presenting without Persistent ST-Segment Elevation of the European Society of Cardiology (ESC). Eur Heart J 2016; 37:267-315. 